"Value in the eye of the beholder: a survey of valuation practices of Estonian financial professionals"

$\begin{array}{ll}\text { AUTHORS } & \text { Mark Kantaukov } \\ \text { Priit Sander }\end{array}$

Mark Kantaukov and Priit Sander (2016). Value in the eye of the beholder: a

ARTICLE INFO survey of valuation practices of Estonian financial professionals. Investment Management and Financial Innovations, 13(2-1), 157-172.

doi:10.21511/imfi.13(2-1).2016.04

DOI

http://dx.doi.org/10.21511/imfi.13(2-1).2016.04

RELEASED ON Monday, 04 July 2016

JOURNAL

"Investment Management and Financial Innovations"

FOUNDER

LLC "Consulting Publishing Company "Business Perspectives"

NUMBER OF REFERENCES

0
NUMBER OF FIGURES

0

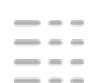

NUMBER OF TABLES

0

(C) The author(s) 2023. This publication is an open access article. 
Mark Kantšukov (Estonia), Priit Sander (Estonia)

\title{
Value in the eye of the beholder: a survey of valuation practices of Estonian financial professionals
}

\begin{abstract}
This is the first empirical study related to the linkage between distributed profit taxation and company valuation. In this paper we present the results of a survey of Estonian valuation practitioners. The main purpose of this study is to clarify the valuation practices of Estonian analysts with emphasis on fundamental analysis-based valuation methods. We elucidate whether and how practitioners treat certain aspects of corporate income taxation when valuing Estonian companies, and how they adjust conventional models taking into account the peculiarities of the Estonian distributed profit taxation system. As distributed profit taxation allows Estonian companies to postpone their income tax liability, it should lead to a positive impact on the value of Estonian companies compared to non-Estonian ones. The survey also included hypothetical valuation cases seeking to determine the difference in analysts' views on equity value in a simplified framework.

Results show that free cash flow to the firm and EV/EBITDA multiples are the most popular valuation models among analysts, with the majority of analysts using these models together. Analysts adjust models primarily when calculating the cost of capital and forecasting corporate income tax liability. However, many respondents did not make any adjustments when valuing Estonian companies, but proceeded from the same grounds when valuing Estonian and non-Estonian businesses. The equity valuation of hypothetical companies revealed highly diverse estimates and an unawareness of the positive aspects of distributed profit taxation vis-à-vis traditional profit taxation on a company's value.
\end{abstract}

Keywords: distributed profit taxation, business valuation, survey analysis, valuation practices, financial professionals, Estonia.

JEL Classification: G12, G20, H25.

\section{Introduction}

A company's valuation tells you more about the analyst than the company.

Author unknown

Valuation and security analysts play an important role in the process of corporate mergers and acquisitions, and also in restructuring of companies, raising capital (including going public), and various litigations. The final value of a deal may deviate from the assessment of an analyst as it settles during the process of negotiations between contracting parties, but value estimates are benchmarks for a deal or asset value. In real life it is inconceivable to build up a valuation model that is fully compatible with theoretical standpoints; however, some basic principles must be followed in order to get a reliable estimated value. The final value estimate becomes questionable if it does not have a solid theoretical basis: in this case there is no difference between doing right things poorly and wrong things correctly. Despite the fact that all valuation approaches have their own disadvantages, one can be sure that financial analysts and financial decision-makers will continue to use them.

The primary aim of this paper is to clarify the valuation practices of Estonian valuation analysts but

C Mark Kantšukov, Priit Sander, 2016.

Mark Kantšukov, Ph.D. Candidate, Lecturer in Finance, School of Economics and Business Administration, University of Tartu, Estonia. Priit Sander, Associate Professor in Finance (Ph.D.), School of Economics and Business Administration, University of Tartu, Estonia. there are other questions under scrutiny. In addition to preferences for appraisal methods we also study adjustments practitioners make when valuing Estonian companies. Valuing companies operating in the Estonian environment is a particularly challenging task: the majority of companies are unlisted SMEs with concentrated ownership. The domestic stock market is small both in terms of market capitalization (1.89 bn EUR as of the end of 2015), market cap to GDP ratio (slightly over $9 \%$ based on 2015 GDP) and the number of listed companies (16 companies as of the end of 2015), which makes it impossible to form a sample of comparables from the set of domestically listed companies. Markets for other securities are also underdeveloped: e.g. bond market capitalization was $82.78 \mathrm{~m}$ EUR as of the end of 2015, and there are no Estonian government bonds on the market. This raises several issues when deriving valuation inputs, such as risk-free rate. (NASDAQ Baltic..., 2016; Ebakõlad Eesti majanduses on suurenenud ..., 2015).

Our more practical task in conducting this survey is related to understanding whether and how valuation practitioners take into account the peculiarities of the Estonian corporate income taxation system. Under Estonian corporate income taxation system, companies do not have to pay corporate income tax on retained earnings; income tax is imposed only on distributed profits which include dividends, share buybacks, share capital reduction, and also fringe benefits (Income Tax Act of Estonia, § 50). In literature it is also referred to as a distributed profit 
(based) taxation (or - DPT) system (see e.g. Hazak, 2007; Hazak, 2008; Hazak, 2009; Masso et al., 2013; Staehr, 2014; Sander et al., 2014). The Estonian system of corporate income taxation is unique as no other country in the world currently employs such an approach to profit taxation.

Companies operating in an environment with DPT still have to pay profit tax, but the tax payment is shifted from the instant of earning the profit to the instant of profit distribution. If a company operating under DPT does not intend to distribute all of its net income for a current year to shareholders then it saves on income tax payable and thus gains an advantage over a company operating under a classical (traditional) taxation system (or TPT). Proceeding from a fundamental principle of the time value of money, the later the cash outflow occurs the better it is for a payer. Saved income tax can be reinvested at a required rate of return to create additional value for the owners of the company. Additional benefits may also occur from a potential decrease in income tax rate by the date the company has to finally pay the tax. In Estonia the statutory income tax rate has fallen since the adoption of the DPT system from $26 \%$ in 2000 to $20 \%$ in 2015 (which is the current rate). These circumstances imply that such enterprises should be more valuable to an investor vis-à-vis peers operating under the traditional profit taxation regime and theoretically should be valued higher.

Citing largely acclaimed valuation models from widely acknowledged textbooks in the case of DPT may lead to serious valuation distortions. Theoretical linkage between distributed profit taxation and company valuation has been discussed in Sander and Kantšukov (2009) and Sander et al. (2014); in those papers it was shown that under a DPT regime corporate financial indicators yield different values compared with those in the environment of traditional profit taxation. The present paper is the first empirical study dealing with valuation under a DPT system from a practical perspective.

Previous empirical company-level studies of DPT effects were carried out by Hazak (2009) and Masso et al. (2013). According to results by Hazak (2009), distributed profit taxation made companies retain profits more and pay dividends less, additionally the importance of external financing of companies decreased. However, companies tended to keep retained earnings as excess cash - that made them more liquid - and not reinvest them into long-term assets. Masso et al. (2013) confirmed that the DPT system contributed to the increase of liquidity and equity of Estonian firms and decrease in their liabilities; less debt-oriented capital structure emerging from the taxation reform of 2000 helped local companies to contrive better the global financial and economic crisis of late 2000s. Also Masso et al. (2013) found there was an increase in companies' investment and productivity, especially among smaller firms, due to the shift to a distributed profit taxation system.

This study contributes to an ongoing discourse about valuation practices in several ways. First of all, when studying valuation adjustments we pay special attention to corrections resulting from the Estonian corporate income taxation system. Secondly, we ask respondents to value hypothetical companies in order to assess consistency of their estimates with theoretical figures from the point of view of tax adjustments. To the best knowledge of the authors, such an approach has not been employed in surveys before. We also contribute to the domain of research on the effects of corporate income taxation on asset valuation as there is a scanty number of academic papers dedicated to the impact of distributed profit taxation on the value of companies.

The rest of the paper is structured as follows. In section 1 we provide a literature overview to accentuate the research gap. We focus on previous surveys of valuation analysts with a brief discussion of possible dissensions between valuation theory and the approaches of practitioners. Section 2 includes a description of the survey design and the sample. Section 3 presents the results of the survey and the last section concludes with a discussion of the results and implications of the study.

\section{Literature review}

The field of research in business valuation is relatively young due to the fact that the majority of valuation models applied in practice were developed during recent decennia. One of the earliest surveys is by Bing (1971) who found that the most frequently used model of valuing companies was the price-to-earnings multiple, whereas estimating value through discounting future dividends was the least preferred. The main conclusion that can be drawn from this study is that practitioners were inclined to use valuation models that were simple to handle.

There are numerous academic surveys conducted in different periods of time among UK security and

cited paper, Arnold and Moizer (1984) found investment analysts. Among others these studies include surveys by Arnold and Moizer (1984), Moizer and Arnold (1984), Arnold et al. (1984), Pike et al. (1993), Barker (1999), Demirakos et al. (2004), Glaum and Friedrich (2006), and Imam et al. (2008).

In their largely that analysts almost always used fundamental analysis instead of technical or beta 
analyses. Among important factors considered in fundamental analysis were estimates of so-called true value of the price-to-earnings ratio which was used to estimate a company's market value; estimates of the NPV of future cash flows (i.e. discounted future cash flows) occurred to be of much less importance. A similar paper by Moizer and Arnold (1984) clarified that portfolio managers analyzed equities in less detail and less frequently than non-portfolio managers. Nevertheless there was no significant difference in analysts' approaches to the valuation of shares. In Arnold et al. (1984) valuation practices of UK and US analysts were studied; the study disclosed significant differences in the practices of analysts from the different countries - US analysts proceeded from more formal analysis than their UK peers. Later Olbert (1994) extended this two-country comparison by surveying Swedish valuation analysts - while Swedish analysts relied as much on fundamental analysis as UK and US analysts, the former used technical analysis much less frequently.

Pike et al. (1993) examined the changes in the approach to share valuation by UK investment analysts; the authors also compared approaches of UK analysts to their German counterparts. As in Arnold and Moizer (1984), UK analysts still preferred earnings and cash flow-based valuation multiples; technical and beta analysis were least favored while discounted cash flow-based techniques were of medium importance. However, results by Glaum and Friedrich (2006) indicated that the majority of analysts specializing in companies in the telecommunications sector used the discounted cash flow (DCF) method as a primary valuation tool. Also, in the post-dotcom-bubble period analysts' practices had shifted to more fundamentally driven and cash flow oriented valuations compared to the pre-bubble period.

Bancel and Mittoo (2014) found that at a broader European level, relative valuation and free cash flow to the firm were the most popular valuation techniques; more than half of the valuation experts applied two or three valuation methods (and around $20 \%$ applied only one valuation method). Of the valuation multiples, the most popular were enterprise value-to-EBITDA (EV/EBITDA) and price-to-earnings $(\mathrm{P} / \mathrm{E})$ ratios. The study also indicated how key parameters in valuation models were estimated. Findings revealed diverse approaches of practitioners to assess leverage, cost of debt, beta coefficients, market risk premiums and other necessary inputs, which is an important issue as divergence in practices may lead to distortions in valuations. Of course, wide variations in valuation practices can be partially explained by the lack of clearly formulated guidelines, absence of data or even absence of the necessary skills; but in some instances experts do not follow recommendations based on financial theory.

Although the vast majority of valuation methods have been developed in the US (or they are represented in US financial textbooks and handbooks) there have been few surveys conducted on the example of US financial analysts. After the survey by Carter and Van Auken (1990), the survey by Block (1999) is practically the only recent survey of US analysts. Results by Block (1999) revealed that present value-based valuation techniques had not been largely used by respondents; they also gave low marks to the capital asset pricing model (CAPM) and dividend discount model techniques. At the same time, respondents highly appreciated the economic value added $\left(\mathrm{EVA}^{\mathrm{TM}}\right)$ approach to valuation. At practically the same time the survey by Johnson and Switzer (2000) was published. However, it was related to the more specific field of divorce valuations.

One can find a remarkable number of surveys of valuation practices conducted in emerging markets during the last couple of decades. It is noteworthy that surveys cover various regions and continents, such as Africa (surveys by Lovell-Greene et al., 1986; Fouche and van Rensburg, 1999; Tijjani et al., 2009), East and Southeast Asia (Mohamad and Nasir, 1997; Saadouni and Simon, 2004; Wang et al., 2011), Persian Gulf countries (Al-Abdulqader et al., 2007; Almujamed et al., 2012), and South America (Pereiro, 2006).

Probably the most cited survey concerning emerging market valuation practices is by Pereiro (2006), who studied investment valuation practices of Argentinian corporations, financial advisors, private equity funds, banks and insurance companies. While DCF was used as the primary valuation tool by the majority of respondents from corporations (89\%) and advisors and private equity funds (73\%), there was a higher proportion of advisors and private equity capitalists who used DCF as a secondary tool (27\% versus $3 \%)$. There was a larger share of respondents who used multiples among advisors and private equity funds compared to corporations. The majority of advisors and private equity funds also applied cross-border corrections for multiples from developed markets; US comparables were used mainly as a starting point. However, as there were only five advisors and six private equity funds in the sample, results for this group of respondents could be considered as neatly allusive.

Based on the preceding review it is possible to claim that, with some differences in the choice of primary tools, valuation practices in emerging markets largely 
correspond to those applied by practitioners in countries with developed capital markets. The majority of surveys from both developed and developing markets indicate stronger preference for multiples than cash flow-based approaches (Arnold and Moizer, 1984; Pike et al., 1993; Barker, 1999; Mohamad and Nassir, 1997; Al-Abdulqader et al., 2007; Tijjani et al., 2009 etc.). A few studies report the opposite (Glaum and Friedrich, 2006; Pereiro, 2006) or indicate that multiples and DCF are more or less of equal importance (Imam et al., 2008; Bancel and Mittoo, 2014). Thus relative valuation and DCF method are the two most frequently employed valuation approaches. This finding is a pretty intuitive outcome in terms of a globalizing world of finance and technology development. Still, some issues related to necessary adjustments in valuation models applied in emerging markets remain open.

Although there is a sufficient number of surveys on analysts' practices of valuation of public companies, there is not so much data on how analysts and corporate decision-makers value unlisted shares, or private companies (private equity). Obviously the process of valuing private companies differs from the valuation of public companies as in the latter case technical and beta analyses are not applicable.

Kantor and Pike (1987) found that when valuing unlisted shares valuators attribute high importance to a company's future earnings prospects. Manigart et al. (1998) studied the practice of European venture capitalists' appraisals of investment projects on the example of the UK, France, Belgium and the Netherlands. While venture capitalists from the UK and France preferred multiples to discounted future cash flows, respondents from Belgium and the Netherlands marked discounted cash flows as their first choice. Venture capitalists also used so-called 'rule of thumb' valuation approaches - industryspecific ratios and recent transaction prices. Vydržel and Soukupová (2012) examined valuation methods used by practitioners in the field of private equity in the Czech Republic; the sample included private equity fund managers and dependent and independent financial advisors. The results indicated that (transaction) multiples and DCF analysis were equally popular although advisors relied on DCF method more than fund managers. Of valuation multiples, enterprise value related multiples EV/EBITDA, EV/Sales, EV/EBIT - were the most widely used. Of DCF models, free cash flow to the firm (FCFF) was the most widely used, followed by free cash flow to equity (FCFE). Sander and Kõomägi (2007) studied the valuation of private companies by private equity and venture capitalists in Estonia. In most of the cases Estonian private and venture capitalists relied on a combination of DCF and multiples, whereas multiples were used as benchmarks for DCF valuations. However, research by Sander and Kõomägi (2007) is based on five case studies and does not allow generalization of practitioners' valuation practices in Estonia.

While all the surveys pay attention to what valuation methods analysts, experts, and managers employ, the issue of compliance of practical approaches with theoretical recommendations is rarely discussed. Of previously mentioned authors only Bancel and Mittoo (2014) deal with the problem of disparities between theory and practice in valuation. It is also possible to refer to papers by Trahan and Gitman (1995), and Graham and Harvey (2001), but they do not focus explicitly on valuation practices. The prolific author on various aspects of valuation, Pablo Fernández, listed 75 valuation errors in Fernández (2003); in the latest (Spanish) version Fernández (2015) even proposed 145 errors.

The authors of this paper were especially interested in whether tax related adjustments and issues were considered in surveys of practitioners as one of the objectives of this study is to clarify whether and how Estonian practitioners take into consideration the peculiarities of the Estonian corporate income taxation system when valuing companies. An important point is that no issue of adjustments proceeding from the peculiarities of corporate income taxation has been considered in previous surveys. Probably this subject has not been considered as all the surveys have been conducted in countries with a classical system of profit taxation.

The previous standpoint is a basis for the opinion that there are too few academic studies dedicated to the issue of disparities between valuation experts' approaches and financial theory at the moment. Despite some websites of legal firms, investment banks and other financial institutions provide miscellaneous lists of the most widespread valuation errors and mistakes, a research gap exists in this field.

Based on the literature review several conclusions can be drawn. Methods of fundamental analysis have prevailed in the set of tools of valuation practitioners - recent evidence suggests that analysts rely primarily on discounted cash flow and multiples-based valuation models. It seems that slowly but steadily DCF-based valuation approaches are gaining popularity although preferences largely depend on the purpose of valuation, circumstances, and the experts themselves. It is also noteworthy that practitioners rarely employ a single valuation method, but rather combine several indicators to reach a more or less objective result. Approaches to estimate key input parameters are also versatile. Surveys of analysts also indicate that there are no 
significant differences between valuation approaches in developed and emerging markets. Academic research on corrections and adjustments made by valuation practitioners in emerging markets is still scanty; the issue has been discussed only in Pereiro (2006).

\section{The structure of the survey}

The survey was conducted on the basis of a questionnaire which was also complemented by personal communication with the analysts. Unlike many previous surveys, we focused on fundamental analysis only as we were also interested in approaches used to value both (Estonian) listed and non-listed companies. The Estonian market for financial advisory services is pretty small compared with those in the US or any Western European country; it consists of a few larger universal and investment banks and audit firms offering a wide range of services in the area of financial consultancy and a dozen smaller companies who offer very specific services. For this reason we did not compile a random sample of analysts but attempted to poll all the analysts working in the industry, especially those employed by larger, well-known institutions.

The questionnaire itself consisted of five sections:

A. General information about the analyst.

B. Questions about methods used in the valuation process and companies under valuation.

C. Questions about cost of capital and capital structure.

D. Questions about aspects related to corporate income taxation.

E. Valuation opinion.

Section A. Data in the first section (age, educational background, length of experience) was requested from analysts in order to compile a characteristic picture of who an average valuation analyst is. We did not ask for names as respondents were granted anonymity.

Section B. Questions in the second section were aimed to determine analysts' preferences for valuation approaches. We asked them to provide an overview of the valuation models that are being used the most (and the least), then to indicate whether a particular model has been used frequently, seldom or never. We also requested analysts to rank the methods used in their preference order. Our special interest was related to "multiples versus DCF" opposition. This section also contained the question on what kind of companies (investment projects) - Estonian or non-Estonian - analysts had typically valued.

On the basis of answers we calculated a so-called popularity score in order to determine the most popular valuation models. The score ranging from 0 to 1 was calculated as follows:

- The option "frequently" was assigned a value of 1 , the option "seldom" was assigned a value of 0.5 and the option "never" was assigned a value of 0 .

- The number of responses for each method in all the categories was multiplied either by $1,0.5$ or 0 and summed up.

Thus, in extreme cases a score equal to 1 means that a particular valuation method is used frequently (or nearly always) and a score equal to 0 means that this method is not used by any of the responding analysts. Of course, this score has many deficiencies as the quantification of qualitative data is very general, but it at least provides some picture of analysts' preferences.

Section C. In the third part of the questionnaire we asked three questions in order to determine how analysts include cost of capital and capital structure as valuation inputs. Questions concerned aspects of book value (i.e. balance sheet value) versus market value of sources of capital, pre-tax weighted average cost of capital (WACC) versus after-tax WACC, and current capital structure versus target (or optimal) capital structure.

Section D. This section addressed the issue of taking into account corporate income taxation in a company's valuation. It included four multiplechoice questions and one open question (consisting of three sub-questions). We asked analysts whether they proceeded from pre-tax or after-tax cash flows (in latter case we asked whether they transformed cash flows to the after-tax level proceeding from a specific dividend payout ratio or if all of the cash flows were brought to the after-tax level), and how they reckon with corporate income tax (proceeding from statutory income tax rate, historical/current or forecasted/estimated effective corporate income tax rate). We also wanted to know whether analysts proceeded from planned dividend payments only or they accounted for other payments subject to corporate income tax (so-called fringe benefits) when forecasting corporate income tax liability.

In the open questions we asked whether and how analysts account for any differences in valuing Estonian companies vis-à-vis non-Estonian ones proceeding from peculiarities of the Estonian corporate income taxation system. As there are three groups of methods - discounted cash flow-based, multiplesbased, and assets-based models - we asked about possible corrections made in each approach.

The issue of adjustments of valuation models was particularly interesting from the standpoint of distributed profit taxation's impact on asset value. 
Different principles of profit taxation affect a company's various financial indicators: inter alia, no interest tax shield (i.e. tax savings on debt financing) should occur in this case as under a distributed profit taxation regime the amount of corporate income tax does not depend on the level of earnings before tax. Previously this issue was discussed from a theoretical perspective in Sander (2005). This in turn impacts cost of capital estimation. Two companies must have different values under different taxation regimes (ceteris paribus). For more discussion one can get familiar with the findings in Sander and Kantšukov (2009).

An interesting byproduct of sections $\mathrm{C}$ and $\mathrm{D}$ was the revelation of potential dissensions in valuation approach, e.g. when an analyst combines pre-tax cost of capital with after-tax cash flows or vice versa. In this situation the estimated asset or company is under- or overvalued.

Section E. This section is considered by the authors of this paper as their original contribution to surveybased research of valuation practitioners. For this reason we provide a more detailed explanation of what was done.

In the last part of the questionnaire we requested analysts' assessments of the equity values of three hypothetical companies. For each of the three companies we provided input data about the company's assets book value $(A)$, return on assets ROA $\left(R_{A}\right)$, cost of capital $\left(k_{a}\right)$, dividend payout ratio $(\delta)$, financial leverage $(d)$, interest rate $(r)$ and income tax rate $(t)$; the full text of the assignments is provided in the questionnaire in the appendix of this paper. Data for the hypothetical companies are presented in the following Table 1.

Table 1. Quantitative inputs for valuation of hypothetical companies

\begin{tabular}{|l|c|c|c|}
\hline & Company A & Company B & Company C \\
\hline Assets (book value), $A$ & $2 \mathrm{mUSD}$ & $2.5 \mathrm{mLVL}$ & $15 \mathrm{mEEK}$ \\
\hline D/A ratio, $d$ & $0 \%$ & $30 \%$ & $30 \%$ \\
\hline $\begin{array}{l}\text { Return on assets } \\
\left(\text { EBIT/A), } R_{A}\right.\end{array}$ & $20 \%$ & $20 \%$ & $20 \%$ \\
\hline Cost of capital, $k_{a}$ & $15 \%$ & $15 \%$ & $15 \%$ \\
\hline Dividend payout ratio, $\delta$ & $50.0 \%$ & $50.0 \%$ & $50.0 \%$ \\
\hline Interest rate on debt, $r$ & - & $8 \%$ & $8 \%$ \\
\hline $\begin{array}{l}\text { Corporate income tax } \\
\text { rate, } t\end{array}$ & $0 \%$ & $15 \%$ & $21 \%(\mathrm{DPT})$ \\
\hline
\end{tabular}

$$
\frac{P}{B_{L, D P T}}=\frac{\left[R_{A} \cdot \delta \cdot(1-d)+\left(R_{A}-k_{a}\right) \cdot d+r \cdot d \cdot t\right]-R_{A} \cdot t \cdot(d+\delta-d \cdot \delta)}{\left[k_{a}-R_{A} \cdot(1-\delta)\right] \cdot(1-d)} .
$$

As one can see the price-to-book ratio of the levered company under DPT should be higher than the price-to-book ratio of the levered company under traditional profit taxation. The important point in the case of companies $\mathrm{B}$ and $\mathrm{C}$ is that the $\mathrm{P} / \mathrm{B}$ value
Conditions for the valuation of the first company (A) were formulated so that it could be valued using a standard dividend discount model (or DDM, also known as the Gordon model). In order to value equity using DDM it is sufficient to know the cost of equity (for an unlevered company this is equal to cost of capital), the dividend payout ratio, and the dividend growth rate (which can be derived from payout ratio, return on assets, and book value of assets). Company B was a hypothetical Latvian company. Unlike company A, it had debt in its capital structure. Analysts were also given the Latvian corporate income tax rate figure $(15 \%$ at the time the survey was conducted; the current tax rate is the same). An important aspect was that company B's return on assets, cost of capital and equity growth rate were the same as in the case of company A. Company $\mathrm{C}$ was a hypothetical Estonian company. It had the same debt-to-assets ratio and interest rate on debt as company $\mathrm{B}$, and the same ROA, cost of capital, and equity growth rate as company A. Also the corporate income tax rate in Estonia (21\% at the time of the survey) was mentioned.

To compare results on a relative basis all estimated equity values were standardized by calculating fundamental price-to-book $(P / B)$ ratios. The vanilla price-to-book ratio for an unlevered company operating in a tax-free environment (the company A in our case) looks as follows (Damodaran, 2014):

$$
\frac{P}{B}=\frac{R_{A} \cdot \delta}{k_{a}-R_{A} \cdot(1-\delta)} \text {. }
$$

Fundamental equity values and $P / B$ ratios for companies $\mathrm{B}$ and $\mathrm{C}$ were calculated using formulas derived in Sander and Kantšukov (2009). According to the results by Sander and Kantšukov (2009) the price-to-book ratio for a levered company operating under traditional profit taxation should equal:

$$
\frac{P}{B_{L, T P T}}=\frac{\left[R_{A} \cdot \delta \cdot(1-d)+\left(R_{A}-k_{a}\right) \cdot d+r \cdot d \cdot t\right]-R_{A} \cdot t}{\left[k_{a}-R_{A} \cdot(1-\delta)\right] \cdot(1-d)} .
$$

And for a similar company operating under distributed profit taxation, the levered $P / B$ ratio should equal: of the Estonian company $\mathrm{C}$ should be higher than that of the Latvian company B despite higher corporate income tax rate for the former company $\left(P / B_{C}=1.79\right.$ and $P / B_{B}=1.67$, see Table 4 in subsection 3.3). The fundamental relative value of 
the equity of company A should be the highest $\left(P / B_{A}=2.00\right)$.

With hypothetical companies B and C, respondents were not supplied with theoretical models applicable for valuation. This means that deviations of analysts' assessments from theoretical ones do not provide enough ground to claim analysts are necessarily wrong (except in the case of company A which is a textbook valuation example). Still, it was interesting to know how diverse analysts' quantitative assessments are, how respondents rank relative equity values of companies $\mathrm{A}, \mathrm{B}$ and $\mathrm{C}$, and how many value estimates were close to results based on models proposed in Sander and Kantšukov (2009). The authors also did not present any guidance or requirements on how the equity of each company should be valued. It was accented that ratios and percentage indicators would remain constant. Analysts were asked to value the companies based solely on the data provided.

When drawing conclusions one has to keep in mind several aspects. First of all, valuation assignments were formulated quite briefly and laconically in order to increase the likelihood of response for this section of the questionnaire (as well as for the questionnaire overall). This means that although the valuation assignment text was written explicitly, there was no guarantee that respondents thought the same way as the authors did. The overwhelming majority of analysts did not wish to specify the conditions of the assignment but there is always something to be lost in translation. Secondly, we did not ask respondents about how they reached their conclusions (to make it less complicated for respondents and thus increase the response rate). This implies that if some of the respondents got an estimate pretty close to (or far from) a theoretically sound one it might have happened due to a good (or bad) guess, not correct calculations.

In conclusion, one can naturally argue about the depth of the questionnaire as many important topics were omitted; one can allude to questionnaires in the previous studies mentioned in this paper. Still, the authors considered the trade-off between the range of aspects covered in the survey and the rate of response. As our main interest was related to the issue of taking into consideration corporate income taxation in valuation, we paid special attention to the respective questions.

The next section of this paper summarizes the results of the survey. In subsection 3.1 we present responses to questions from part A and part $\mathrm{B}$ of the questionnaire, in subsection 3.2 we analyze responses to questions from part $\mathrm{C}$ and part $\mathrm{D}$, and subsection 3.3 summarizes the results of part $\mathrm{E}$.

\section{Results}

3.1. Analysts' background and their preferences for valuation methods. In total we collected 32 responses from 26 companies; with more than one analyst responding from some companies. The most intensive period of response collection was MayAugust 2010 but some responses arrived later, August 2011 being the latest. Initially the questionnaire was sent to 27 companies but some analysts did not respond due to questions in the last section of the questionnaire which are the most time-demanding to answer or for reasons of busyness and/or unwillingness to disclose information. Sample companies are presented in the following Table 2 .

Table 2. Sample composition by company type

\begin{tabular}{|c|c|c|}
\hline Credit institutions & $\begin{array}{l}\text { Asset management } \\
\text { companies }\end{array}$ & $\begin{array}{c}\text { Private equity \& } \\
\text { mezzanine companies }\end{array}$ \\
\hline - Swedbank & $\begin{array}{ll}\text { Avaron Asset } \\
\text { Management } \\
\text { LHV Varahaldus }\end{array}$ & $\begin{array}{ll}\text { Hanseatic } \\
\text { Capital } \\
\text { Baltic } \\
\text { Mezzanine }\end{array}$ \\
\hline Audit firms & $\begin{array}{l}\text { Investment firms \& } \\
\text { investment banks }\end{array}$ & $\begin{array}{c}\text { Miscellaneous } \\
\text { financial consultants }\end{array}$ \\
\hline $\begin{array}{ll}\text { EY } \\
\text { (former Ernst \& } \\
\text { Young) } \\
\text { KPMG } \\
\text { PwC } \\
\text { - Rimess }\end{array}$ & $\begin{array}{ll}- & \text { SEB Enskilda } \\
& \text { GILD Financial } \\
& \text { Advisory } \\
& \text { Services } \\
& \text { Redgate Capital } \\
& \text { Nordic CF } \\
& \text { Advisory } \\
\text { - } & \text { Evli Securities } \\
\text { Arlig Capital }\end{array}$ & $\begin{array}{ll} & \text { Advisio } \\
& \text { Business } \\
& \text { Advisor } \\
\text { Eneseteostuse } \\
\text { - } & \text { Finantsplaan } \\
\text { Innopolis } \\
\text { Investment } \\
\text { SP Navitas } \\
\text { Tark Investor } \\
\text { Sentio } \\
\text { Keystone } \\
\text { Advisers } \\
\text { Rödl \& Partner }\end{array}$ \\
\hline
\end{tabular}

On the basis of the sample the conducted survey can be considered solid: taking into account the size of the Estonian market for financial advisory based on any indicator (sales revenue, number of analysts or companies), the number of responses is sufficient to generalize the situation with Estonian practitioners' approaches to company valuation. The authors of the study could not reach every last freelance analyst, but had additional responses occasionally occurred later they would not have significantly altered the general picture. Also, when comparing the number of responses with those of previous studies, the present survey can be regarded representative in relative terms: Arnold, Moizer (1984) had responses from 202 UK analysts, AlAbdulqader (2007) from 224 Saudi investors, Wang et al. (2009) from 65 Chinese analysts, and the sample by Vydržel and Soukupová (2012) included 45 managers and analysts.

In our sample the analysts' median age was 27 years at the time of response (with a standard deviation of 
6.6 years), which characterizes the youth of employees in the sector. The respondents' median professional valuation experience was 5 years. Most of the analysts have at least a bachelor's degree in economics or business administration, but there was also a large portion of respondents who have a master's degree and are even in their doctoral studies. Most of the respondents have graduated either from the University of Tartu or Tallinn University of Technology. With provision one can state that responses are largely affected by the analysts' educational backgrounds, especially taking into account the relatively young age of respondents. Estonian analysts use all the most widespread valuation methods with various frequency as presented in the following Table 3 .

Table 3. Frequency of use of valuation methods by survey respondents with popularity score

\begin{tabular}{|l|c|c|c|c|}
\hline \multicolumn{5}{|c|}{ Discounted cash flows-based models } \\
\hline & Often & Seldom & Never & Score \\
\hline FCFF & 26 & 4 & 2 & 0.875 \\
\hline FCFE & 10 & 16 & 6 & 0.563 \\
\hline $\begin{array}{l}\text { Dividend discount models } \\
\text { (DDM) }\end{array}$ & 1 & 13 & 18 & 0.234 \\
\hline Other & 2 & 1 & 29 & 0.078 \\
\hline APV & 0 & 3 & 29 & 0.047 \\
\hline \multicolumn{7}{|c|}{ Multiples-based models } \\
\hline & Often & Seldom & Never & Score \\
\hline EV/EBITDA & 25 & 2 & 5 & 0.813 \\
\hline P/E & 18 & 7 & 7 & 0.672 \\
\hline EV/Sales & 14 & 11 & 7 & 0.609 \\
\hline P/B & 15 & 7 & 10 & 0.578 \\
\hline EV/EBIT & 13 & 11 & 8 & 0.578 \\
\hline EV/Assets & 2 & 11 & 19 & 0.234 \\
\hline P/EBIT & 3 & 7 & 22 & 0.203 \\
\hline Other & 5 & 2 & 25 & 0.188 \\
\hline P/EBT & 2 & 7 & 23 & 0.172 \\
\hline \multicolumn{5}{|c|}{ Asset-based models } \\
\hline Often & Seldom & Never & Score \\
\hline Book value of assets & 11 & 14 & 7 & 0.563 \\
\hline Liquidation value of assets & 9 & 18 & 5 & 0.563 \\
\hline Replacement value of assets & 7 & 17 & 8 & 0.484 \\
\hline
\end{tabular}

One can see that among discounted cash flow-based models, free cash flow to the firm, FCFF, is an indisputable leader followed by FCFE; the APV model is hardly ever used. This can be explained by overall prevalence of the FCFF model in literature on valuation, as well as in the financial industry worldwide, as the literature overview suggests. Additionally, application of the APV model is aggravated by assessing additional effects of debt financing, especially bankruptcy costs.

Among valuation multiples EV/EBITDA is the most widely used by Estonian valuation analysts followed by the P/E multiple. Popularity of the EV/EBITDA ratio is largely in concordance with evidence from previous surveys (e.g. Vydržel and Soukupová, 2012). Frequent use of the EV/EBITDA ratio can be also explained by the fact that EBITDA is a good approximation of free cash flow, which a company's value depends on. A surprising revelation was that the P/EBT multiple scored so low taking into account the peculiarity of the Estonian corporate income taxation system. As the case of Estonian companies is that the difference between pre-tax income and net income is a function of the company's dividend policy (the amount of dividends the company paid out during a particular year), then P/EBT ratio would be more appropriate to use when valuing Estonian firms using multiples of non-Estonian public companies.

There are analysts who do not use valuation multiples at all and vice versa - there are analysts who don't trust estimates received by discounting expected cash flows. The former analysts present as an argument the lack of comparable companies in Estonia in many sectors and inappropriateness of using valuation multiples of companies listed on foreign stock exchanges; the latter analysts refer to a high sensitivity of DCF valuations to various input factors which leaves room for manipulation. However, 20 analysts (62.5\% of total respondents) frequently use both the FCFF method and the EV/EBITDA ratio.

We've also learned that respondents deal mainly with the valuation of Estonian privately held companies - 26 analysts (81.3\% of respondents) have marked this option; 7 analysts $(21.9 \%$ of respondents) analysts value only non-listed Estonian firms. Still, approximately two thirds of respondents, 21, value more than one kind of company (i.e. Estonian and non-Estonian, public and non-listed). There are also analysts in the sample who do not value Estonian companies.

3.2. Cost of capital, capital structure and adjustments in valuation models. $56.3 \%$ of respondents use the market value of sources of capital which is in accordance with financial theory, $31.3 \%$ of analysts use the book value of weights. Four analysts $(12.5 \%)$ have noted that they use both the market and the book value of weights. The latter fact leaves plenty of room for interpretation but several explanations can be provided: sometimes it is hard or impossible to assess the market value of sources of capital (e.g. in the case of start-ups), and in price-regulated companies it is recommended to estimate WACC using the book value of weights (see Sander, 2009). In addition, using the book value of weights helps avoid the so-called circularity problem - one must know the cost of capital to value a company but also needs to know the value of a company to properly estimate the cost 
of capital. Also, selection of the book or market value of weights may depend on a client's interests (to show higher or lower cost of capital and the value of an asset).

There is a prevailing propensity among analysts to use after-tax WACC. 19 of 32 respondents (or $59.4 \%$ of respondents) use after-tax WACC whilst 12 analysts use pre-tax WACC. At the same time one analyst noted the use of both after-tax and pretax WACC. Of course, it is possible to use both pretax and after-tax cost of capital in valuation; one only has to keep in mind whether tax-adjusted (or unadjusted) cost of capital is used to discount taxadjusted (or unadjusted) cash flows.

Regarding the use of pre-tax and after-tax cash flows the proportion of different responses is more or less equal (16 analysts use pre-tax cash flows, 15 analysts use after-tax cash flows; one person uses both pre-tax and after-tax cash flows). This revealed a contradiction in valuation approach: four analysts (or $12.5 \%$ of all the respondents) combine pre-tax cash flows with after-tax cost of capital. Such an approach (ceteris paribus) leads to an overvaluation of assets (cash flows are not netted of taxes whereas cost of capital is cleaned of income tax). Also, as one analyst has marked that he uses pre-tax and after-tax WACC (and cash flows) then it was not possible to claim dissension in this case.

We asked those analysts who rely on after-tax cash flows whether they use specific (dividend) payout ratios or if they bring all the cash flows onto an after-tax level. Most of the analysts, nine of 15, have stated that they bring all the cash flows on after-tax level; five analysts would proceed from specific payout ratios; one analyst marked both options.

When keeping in mind the scope of the survey one of the important questions was related to how analysts would reckon with corporate income tax in company valuation. As in Estonia companies pay income tax depending on the amount of dividends paid, then effective income tax rate is closely related to the company's expected dividend policy. Half of the respondents proceeded from all the suggested options - statutory corporate income tax rate and historical/current and forecasted effective corporate income tax rate. 12 analysts proceeded solely from the statutory corporate income tax rate. Although tax liability of Estonian companies is determined mostly by dividend payments, there are other payments made by companies subject to income tax (e.g. fringe benefits). However, only two analysts take into account other payments taxed by corporate income tax in the valuation of companies.

Prior to the survey the authors' expectation was that Estonian analysts would adjust traditional models when valuing Estonian companies. Surprisingly, 13 analysts (40.6\% of respondents) have stated that they proceed from the same grounds when valuing Estonian and non-Estonian companies and do not take into account the peculiarities of the Estonian corporate income taxation system. Practitioners who implement tax-specific adjustments in their valuations specified most frequently that they correct WACC for income tax (no interest tax shield exists for Estonian companies, i.e. cost of debt should be pre-tax in Estonian cases) or terminal value, some analysts do not take into account corporate income tax liability if companies haven't paid dividends. The fact that respondents adjust WACC for income tax is similar to the finding by Kantšukov and Loemaa (2012) according to which the majority (55\%) of surveyed Estonian analysts neglect taxrelated aspects in cost of capital estimation.

Other corrections were related to various premiums and discounts. A couple of analysts in the sample preferred pre-tax earnings or EBITDA/EBIT-based multiples as they are not affected by profit tax.

3.3. Analysts' estimates of equity value of hypothetical companies. Of 32 surveyed analysts, 25 provided their estimates for equity values of hypothetical companies on the basis of which estimated P/B ratios were calculated. Summarized results are presented in the following figure. For reasons of clarity only theoretical, minimal, maximal, and median estimated $\mathrm{P} / \mathrm{B}$ ratios for each hypothetical company are depicted. The median was preferred to the average to smoothen the impact of extreme estimated values. 


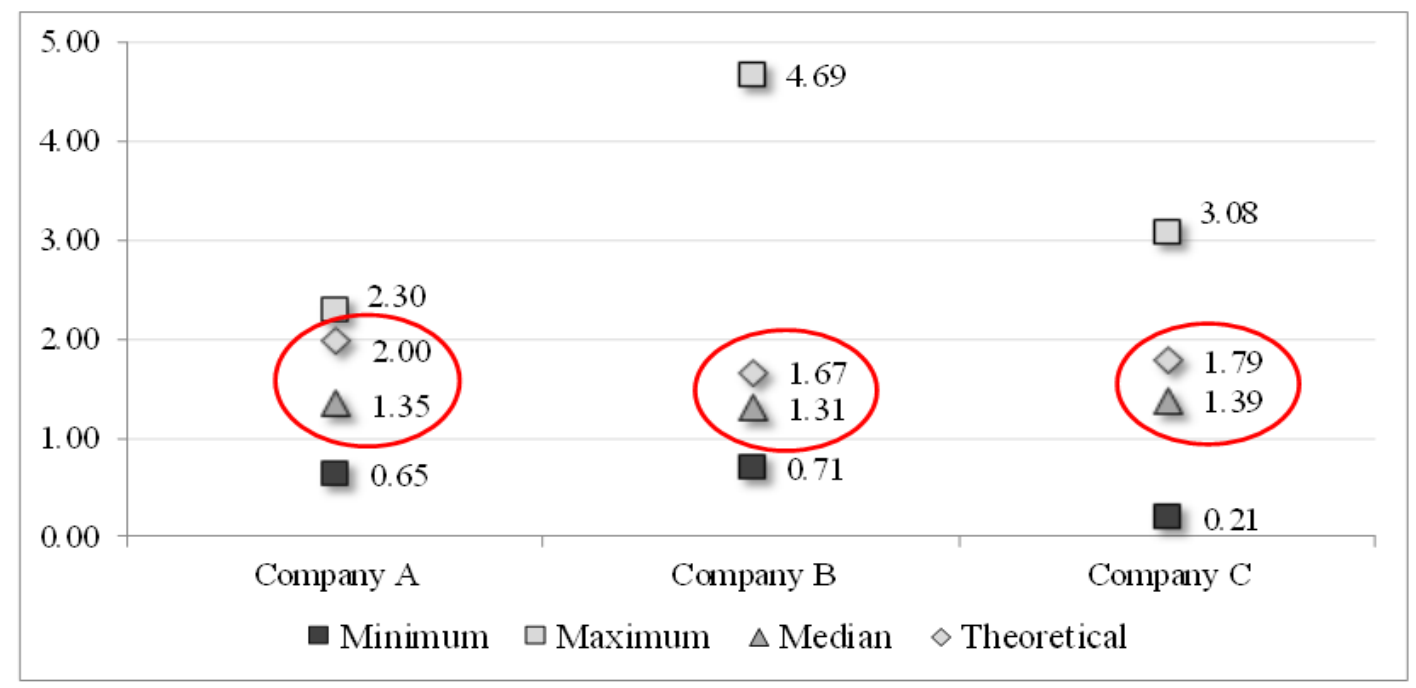

Fig. 1. Median, minimum and maximum estimated versus theoretical price-to-book ratios for three hypothetical companies

Various appraisal error characteristics for these valuation cases are presented in the following Table 4.

Table 4. Error characteristics for valuation cases of hypothetical companies

\begin{tabular}{|l|c|c|c|}
\hline & $\begin{array}{c}\text { Company } \\
\mathrm{A}\end{array}$ & $\begin{array}{c}\text { Company } \\
\mathrm{B}\end{array}$ & $\begin{array}{c}\text { Company } \\
\mathrm{C}\end{array}$ \\
\hline $\begin{array}{l}\text { Equity market value } \\
\text { (theoretical) }\end{array}$ & $\begin{array}{c}4.00 \\
\mathrm{mUSD}\end{array}$ & $2.93 \mathrm{mLVL}$ & $\begin{array}{c}18.82 \\
\mathrm{mEEK}\end{array}$ \\
\hline Equity book value & $\begin{array}{c}2.00 \\
\mathrm{mUSD}\end{array}$ & $1.75 \mathrm{mLVL}$ & $\begin{array}{c}10.50 \\
\mathrm{mEEK}\end{array}$ \\
\hline P/B ratio (theoretical) & 2.00 & 1.67 & 1.79 \\
\hline $\begin{array}{l}\text { Standard deviation of the } \\
\text { estimate }\end{array}$ & $\begin{array}{c}1.03 \\
\mathrm{mUSD}\end{array}$ & $1.53 \mathrm{mLVL}$ & $6.55 \mathrm{mEEK}$ \\
\hline $\begin{array}{l}\text { Coefficient of variation of the } \\
\text { estimate }\end{array}$ & $32.5 \%$ & $52.1 \%$ & $41.4 \%$ \\
\hline $\begin{array}{l}\text { Correct valuations, } \\
\text { percentage of total }\end{array}$ & $\begin{array}{c}24.0 \% \\
140.0 \%\end{array}$ & $0.0 \%$ & $0.0 \%$ \\
\hline $\begin{array}{l}\text { Overvaluations, percentage of } \\
\text { total }\end{array}$ & $20.0 \%$ & $32.0 \%$ & $24.0 \%$ \\
\hline $\begin{array}{l}\text { Undervaluations, percentage } \\
\text { of total }\end{array}$ & $56.0 \%$ & $68.0 \%$ & $76.0 \%$ \\
\hline Minimum percentage error & $-67.5 \%$ & $-57.3 \%$ & $-88.5 \%$ \\
\hline Maximum percentage error & $15.0 \%$ & $179.9 \%$ & $71.7 \%$ \\
\hline Mean percentage error & $-20.5 \%$ & $0.4 \%$ & $-15.8 \%$ \\
\hline $\begin{array}{l}\text { Mean absolute percentage } \\
\text { error (APE) }\end{array}$ & $24.9 \%$ & $36.8 \%$ & $31.6 \%$ \\
\hline $\begin{array}{l}\text { Percentage of valuations with } \\
\text { APE < 10\% }\end{array}$ & $40.0 \%$ & $8.0 \%$ & $20.0 \%$ \\
\hline $\begin{array}{l}\text { Percentage of valuations with } \\
\text { APE < 25\% }\end{array}$ & $48.0 \%$ & $44.0 \%$ & $40.0 \%$ \\
\hline $\begin{array}{l}\text { Percentage of valuations with } \\
\text { APE < 50\% }\end{array}$ & $88.0 \%$ & $84.0 \%$ & $84.0 \%$ \\
\hline
\end{tabular}

The first remarkable thing is a relatively high variance of estimated values for company A although this valuation case can be considered a simple textbook example. While the theoretical $P / B$ ratio of the company equals 2.00 , generally analysts undervalued company A by $20.5 \%$. However, it should be noted that six of 25 analysts provided the theoretically correct answer; results of four more analysts could also be considered correct due to equivocation in formulated conditions concerning equity growth rate (that's why there are two values in the respective cell in the Table $4-24 \%$ and $40 \%$ ). The amplitude of estimates for the equity value of company B was conspicuously wide, although the mean percentage error was remarkably low, only $0.4 \%$. At the same time as the theoretical $\mathrm{P} / \mathrm{B}$ ratio was 1.67 , the median estimated $\mathrm{P} / \mathrm{B}$ was 1.31. While none of the analysts provided an absolutely correct estimate for the equity value of company B there were two analysts whose estimates had an APE of less than 10\% (compared with the theoretical one). The median value of the estimated $\mathrm{P} / \mathrm{B}$ ratio of company $\mathrm{C}$ was lower than its theoretical value but there was a significant range of extreme estimates compared to both theoretical and median values. While none of the analysts provided absolutely correct estimates for the equity value of company $\mathrm{C}$ there were 5 analysts whose APE was less than $10 \%$ compared with the theoretical one. Nevertheless, on average analysts undervalued the equity of company $\mathrm{C}$ by $15.8 \%$. It is remarkable that one analyst has an average percentage error of $4.8 \%$ over his estimates for all three companies.

Comparing the results of valuation by the companies it is possible to claim that on a median basis analysts considered the equity values of these three companies more or less equal, whereas the median P/B ratio for the Estonian company was the highest. Only 4 analysts (out of 25) presented their estimates so that ranking of values is correct, i.e. $P / B_{A}>P / B_{C}>P / B_{B}$ (albeit their equity estimates are not correct).

The ample range of the equity estimates for companies B and C leads to the thought that if even a small amount of inputs and a relatively simple valuation setting can produce high variance of final estimates, especially in the absence of peer group companies, then it would be very hard to achieve conformity of analysts' views on the value of some 
real-life company. Also it is odd that a couple of analysts estimated fundamental values of equities for all the companies to be lower than their book values, taking into account that there were no explicit reasons for such a conclusion, especially in the case of company A where return on assets is higher than cost of capital, there's no debt, and no profit tax. Also, the impact of distributed profit taxation on asset value is not acknowledged by any of the valuation analysts in Estonia.

Of course, presence of solutions would allow clarification of how analysts reached their estimates, and where these differences in valuations occurred from. Based on the high variance of equity value estimates for companies $\mathrm{B}$ and $\mathrm{C}$ it is not necessarily wrong to claim that analysts do not have sufficient knowledge to estimate equity values for these companies, there is just not enough data to support that claim. However, the relatively large deviation in estimates of the equity value for company $\mathrm{A}$ is evidence that some analysts have serious issues with valuation basics if they cannot correctly calculate the value of an asset using the Gordon growth (i.e. dividend discount) model. Although our findings indicate that the dividend discount model is rarely used by Estonian analysts, this is a must-know for any valuation practitioner.

\section{Conclusions and discussion}

This study contributes to the conglomeration of surveys on analysts' valuation practices in emerging markets. As the majority of Estonian companies are privately held we focused entirely on fundamental analysis-based methods. The sample consisted of practitioners working for asset management companies, audit firms, investment firms, banks, miscellaneous financial consultation companies and freelance advisors.

The findings indicate that Estonian valuation practitioners prefer the same methods of fundamental analysis as their peers in other countries. Generally, valuation analysts combine several valuation methods, such as the discounted cash flow analysis and multiples - this finding is in concordance with the conclusion by Bancel and Mittoo (2014). FCFF and EV/EBITDA are the most popular models and they are used together by the majority of analysts. It is positive that, by and large, analysts are inclined to use cash flow-based models: FCFF and FCFE. These results are in a certain correspondence with results by Glaum and Friedrich (2006), Pereiro (2006) and Vydržel and Soukupová (2012). However, there are analysts who do not use either multiples or cash flow-based models at all due to lack of comparable companies on the Estonian market or high sensitivity of estimates to the changes in the values of inputs. Surveyed analysts deal mostly with the valuation of Estonian privately held companies, although a large proportion of practitioners value more than one kind of company.

The majority of analysts proceeded from the market value of weights when estimating cost of capital, which is in conformity with financial theory; also, most of the respondents proceeded from after-tax WACC. Results of the analysis revealed some discrepancies in analysts' practices as some of them combine pre-tax WACC with after-tax cash flows and vice versa. A remarkable proportion of analysts proceeded from the same grounds when valuing Estonian and non-Estonian companies and do not implement any adjustments. However, the majority of respondents apply various adjustments or corrections; although this practice is very heterogeneous different analysts refer to different adjustments. Also, our survey revealed diverse views of analysts on equity estimates in a simple valuation framework.

Our study has several implications. First of all, the authors would like to stress that companies operating under distributed profit taxation should not be valued on the same grounds as companies operating under traditional profit taxation, and practitioners should acknowledge the impact of DPT on valuations, at least on an intuitive level. In addition to adjustments related to marketability, country risk, deriving a suitable proxy for risk-free rate etc. income tax-based adjustments shall be made when valuing Estonian companies. It is positive that a significant number of analysts treat Estonian companies and non-Estonian ones differently. Secondly, as some analysts could not correctly derive equity value in a simple dividend discount model setting, issues about potential errors made in real valuation cases crop up. Of course, the latter aspect raises issues about professional training of analysts as well. Thirdly, if professional valuation analysts have very different views of the same asset (company) value then the question whose judgment non-experts should trust can be raised. This is a vital problem taking into account the costliness of financial advisory services.

There are several limitations to our research. The authors of any survey desire to involve more respondents in order to get more convincing results. Proceeding from a trade-off between the analysts' response ratio and the depth of the study, the authors chose to compile a rather brief but focused questionnaire in order to obtain a larger sample. However, there were more questions the authors would have liked to ask, e.g. questions on sources of valuation inputs. While surveys may give a good hint of what valuation analysts do, it is questionable 
whether a survey can give a good image of how they do it. Knowing how analysts value companies provides a better understanding of valuation practices and potential inconsistencies and mistakes in valuation. For further development of this survey, the authors propose an empirical research on how analysts derive their valuation estimates.

\section{Acknowledgments}

The authors would like to express their gratitude to the anonymous referee and associate professor Tõnu Roolaht for their valuable comments and remarks on the paper, and Mr. Nicholas Shane Vandrey for proofreading.

\section{References}

1. Al-Abdulqader, K.A., Hannah, G. \& Power, D.M. (2007). The appraisal of ordinary shares by Saudi investors, Research in International Business and Finance, 21 (1), pp. 69-86.

2. Almujamed, H. I., Fifield, S.G.M. \& Power D.M. (2012). Share Valuation Methods And Data Source-Based Accounting In An Emerging Stock Market: The Case Of The Kuwaiti Stock Market, International Business \& Economics Research Journal, 11(7), pp. 713-730.

3. Arnold, J.A., \& Moizer, P. (1984). A Survey of the Methods Used by UK Investment Analysts to Appraise Investments in Ordinary Shares, Accounting and Business Research, 14(55), pp. 195-207.

4. Arnold, J.A., Moizer, P. \& Noreen, E. (1984). Investment Appraisal Methods of Financial Analysts: A Comparative Survey of US and UK Practices, International Journal of Accounting, Spring, pp. 1-18.

5. Bancel, F. \& Mittoo, U.R. (2014). The Gap between the Theory and Practice of Corporate Valuation: Survey of European Experts, Journal of Applied Corporate Finance, 26(4), pp. 106-117.

6. Barker, R.G. (1999). The role of dividends in valuation models used by analysts and fund managers, The European Accounting Review, 8(2), pp. 195-218.

7. Bing, R.A. (1971). Survey of Practitioners' Stock Evaluation Methods, Financial Analysts Journal, May-June, pp. 55-60.

8. Block, S.B. (1999). A Study of Financial Analysts: Practice and Theory, Financial Analysts Journal, July-August, pp. 86-95.

9. Carter, R. \& Van Auken, H. (1990). Security Analysis and Portfolio Management: A Survey and Analysis, Journal of Portfolio Management, Spring, pp. 81-85.

10. Damodaran, A. (2014). Applied Corporate Finance, 4th ed., Wiley.

11. Demirakos, E.G., Strong, N.C. \& Walker, M. (2004). What Valuation Models Do Analysts Use? Accounting Horizons, 18(4), pp. 221-240.

12. Ebakõlad Eesti majanduses on suurenenud, press release of Bank of Estonia 09.12.2015. Available at: http://www.eestipank.ee/press/ebakolad-eesti-majanduses-suurenenud-09122015. Accessed on: 4 January 2016.

13. Fernández, P. (2003). 75 Common and Uncommon Errors in Company Valuation, 28 p. Available at SSRN: http://papers.ssrn.com/sol3/papers.cfm?abstract_id=411600. Accessed on: 20 December 2015.

14. Fernández, P. (2015). 145 Errores en Valoraciones de Empresas, 44 p. Available at SSRN: http://papers.ssrn.com/ sol3/papers.cfm?abstract_id=962921. Accessed on: 20 December 2015.

15. Fouche, S. \& van Rensburg, P. (1999). A survey of the investment appraisal techniques used by South African unit trust portfolio managers, Investment Analyst Journal, 28(49), pp. 19-29.

16. Glaum, M. \& Friedrich, N. (2006). After the "Bubble": Valuation of Telecommunication Companies by Financial Analysts, Journal of International Financial Management and Accounting, 17(2), pp. 160-174.

17. Graham, J.R. \& Harvey, C.R. (2001). The theory and practice of corporate finance: evidence from the field, Journal of Financial Economics, 60(2-3), pp. 187-243.

18. Hazak, A. (2007). Dividend Decision Under Distributed Profit Taxation: Investor's Perspective, International Research Journal of Finance and Economics, Issue 9, pp. 201-219

19. Hazak, A. (2008). Profit vs. distributed profit based taxation and companies' capital structure, International Journal of Entrepreneurship and Innovation Management, 8(5), pp. 524-541

20. Hazak, A. (2009). Companies' Financial Decisions under the Distributed Profit Taxation Regime of Estonia, Emerging Markets Finance and Trade, 45 (4), pp. 4-12.

21. Imam, S., Barker, R. \& Clubb, C. (2008). The Use of Valuation Models by UK Investment Analysts, European Accounting Review, 17 (3), pp. 503-535.

22. Income Tax Act of Estonia. Available at: https://www.riigiteataja.ee/en/eli/ee/518062015017/consolide/current. Accessed on: 4 January 2016.

23. Johnson, F.P. \& Switzer, R.V. (2000). Evaluating a Valuation Analyst's Methods For Determining the Value of a Closely Held Commercial Business in a Divorce Action, American Journal of Family Law, 14, pp. 155-163.

24. Kantšukov, M. \& Loemaa, J. (2012). Estimation of cost of capital in emerging markets: the case of Estonia, Economics and Management, 17(1), pp. 77-83.

25. Lovell-Greene, N.J., Affleck-Graves, J.F. \& Money A.H. (1986). A survey of investment appraisal methods use by financial analysts in South Africa, The Investment Analyst Journal, 28, November, pp. 7-17.

26. Manigart, S., Wright, M., Robbie, K., Desbrières, P. \& De Waele, K. (1997). Venture Capitalists' Appraisal of Investment Projects: An Empirical European Study, Entrepreneurship: Theory and Practice, 21 (4), pp. 29-43. 
27. Masso, J., Meriküll, J. \& Vahter, P. (2013). Shift from gross profit taxation to distributed profit taxation: are there effects on firms? Journal of Comparative Economics, 41(4), 1092-1105.

28. Mohamad, S. \& Nasir, A. (1997). A Survey of Methods Used by Malaysian Brokerage Firm Investment Analysts to Appraise Investments in Ordinary Shares, Pertanika Journal of Social Sciences \& Humanities, 5(2), pp. 125-137.

29. Moizer, P. \& Arnold, J. (1984). Share Appraisal by Investment Analysts - Portfolio vs. Non-Portfolio Managers, Accounting and Business Research, 14(56), pp. 341-348.

30. NASDAQ Baltic: Market Capitalization. Available at: http://www.nasdaqbaltic.com/market/?pg=capital. Accessed on: 4 January 2016.

31. Pereiro, L.E. (2006). The practice of investment valuation in emerging markets: Evidence from Argentina, Journal of Multinational Financial Management, 16, pp. 160-183.

32. Pike, R., Meerjanssen, J. \& Chadwick, L. (1993). The Appraisal of Ordinary Shares by Investment Analysts in the UK and Germany, Accounting and Business Research, 23(92), pp. 489-499.

33. Saadouni, B. \& Simon, J. (2004). Methods used by Thai and Malaysian security analysts to appraise ordinary shares, Asian Review of Accounting, 12(2), pp. 25-56.

34. Sander, P. (2005). Laenukapitali maksueelis Eestis - mü̈̈t või reaalsus. In: Eesti ettevõtluse perspektiivid Euroopa Liidus 2005 - III teadus- ja koolituskonverents, Mattimar OÜ, pp. 169-177.

35. Sander, P. (2009). Cost of Capital in Price-regulated Companies: the Case of Estonia. In: XVII rahvusvaheline majanduspoliitika teaduskonverents "Majanduspoliitika Euroopa Liidu riikides - aasta 2009”, 1.-3. juuli 2009, Värska. Ed. Sulev Mäeltsemees, Janno Reiljan. Berliner Wissenschafts-Verlag, pp. 345-356.

36. Sander, P. \& Kantšukov, M. (2009). Effect of corporate taxation system on profitability and market ratios - the case of ROE and P/B ratios, Research in Economics and Business: Central and Eastern Europe, 1(28), pp. 27-40.

37. Sander, P. \& Kõomägi, M. (2007). Valuation of private companies by Estonian private equity and venture capitalists, Baltic Journal of Management, 2(1), pp. 6-19.

38. Sander, P., Teder, A., Viikmaa, K. \& Kantšukov, M. (2014). The Distributed Profit Based Corporate Taxation, and the Valuation of Cash Holdings, International Journal of Trade, Economics and Finance, 5(3), pp. 212-217.

39. Staehr, K. (2014). Corporate Income Taxation in Estonia. Is It Time to Abandon Dividend Taxation? TUTECON Research Brief No. RB-2014/1, 11 p. Available at: http://www.tutecon.eu/index.php/TUTECON/article/view/9. Accessed on 20 December 2015

40. Tijjani, B., Fifield, S.G.M. \& Power, D.M. (2009). The appraisal of equity investments by Nigerian investors, Qualitative Research in Financial Markets, 1(1), pp. 6-26.

41. Trahan, E.A. \& Gitman, L.J. (1995). Bridging the Theory-Practice Gap in Corporate Finance: A Survey of Chief Financial Officers, The Quarterly Review of Economics and Finance, 35(1), pp. 73-87.

42. Vydržel, K. \& Soukupová, V. (2012). Empirical Examination of Valuation Methods Used in Private Equity Practice in the Czech Republic, The Journal of Private Equity, 16(1), pp. 83-99.

43. Wang, J., Haslam, J. \& Marston, C. (2011). The appraisal of ordinary shares by Chinese financial analysts, Asian Review of Accounting, 19(1), pp. 5-30.

\section{Appendix}

Survey questionnaire (translation from Estonian)

\section{A. General information about the analyst.}

Your age

What is your educational background (college/university, faculty/department, specialization, degree)?

How many years have you been dealing with valuation of companies (including various investment projects)?

\section{B. Questions about methods used in valuation process and companies under valuation.}

1. Which methods do you use in companies valuation?

\begin{tabular}{|l|c|c|c|}
\hline \multicolumn{4}{|c|}{ Discounted cash flows-based models } \\
\hline & Frequently & Seldom & Never \\
\hline FCFF & $\square$ & $\square$ & $\square$ \\
\hline FCFE & $\square$ & $\square$ & $\square$ \\
\hline APV & $\square$ & $\square$ & $\square$ \\
\hline Discounted dividends models & $\square$ & $\square$ & $\square$ \\
\hline & $\square$ & $\square$ & $\square$ \\
\hline
\end{tabular}




\begin{tabular}{|l|c|c|c|}
\hline \multicolumn{4}{|c|}{ Multiples-based models } \\
\hline EV/EBITDA & Frequently & Seldom & Never \\
\hline EV/EBIT & $\square$ & $\square$ & $\square$ \\
\hline EV/Sales & $\square$ & $\square$ & $\square$ \\
\hline EV/Assets & $\square$ & $\square$ & $\square$ \\
\hline P/E & $\square$ & $\square$ & $\square$ \\
\hline P/EBIT & $\square$ & $\square$ & $\square$ \\
\hline P/EBT & $\square$ & $\square$ & $\square$ \\
\hline P/B & $\square$ & $\square$ & $\square$ \\
\hline \multicolumn{5}{|c|}{ Asset-based models } & $\square$ & $\square$ \\
\hline Brequen value of assets & $\square$ & $\square$ & $\square$ \\
\hline Liquidation value of assets & $\square$ & $\square$ & $\square$ \\
\hline Replacement value of assets & $\square$ & $\square$ & $\square$ \\
\hline
\end{tabular}

2. Please rank the models used in their preference order (starting from the most preferred)

\begin{tabular}{|l|l|}
\hline 1 & \\
\hline 2 & \\
\hline 3 & \\
\hline 4 & \\
\hline 5 & \\
\hline 6 & \\
\hline 7 & \\
\hline 8 & \\
\hline$\ldots$ & \\
\hline
\end{tabular}

3. What kind of companies (investment projects) do you value?

$\square \quad$ Estonian listed (public) companies

$\square \quad$ Estonian non-listed companies

$\square \quad$ Non-Estonian listed (public) companies

$\square \quad$ Non-Estonian non-listed companies

$\square \quad$ Listed (public) companies operating on several markets

$\square \quad$ Non-listed companies operating on several markets

\section{Questions about cost of capital and capital structure.}

4. When calculating weights of different sources to estimate cost of capital you usually proceed from:

Book value of sources of capital

Market value of sources of capital

5. When estimating weighted average cost of capital (WACC) you usually proceed from:

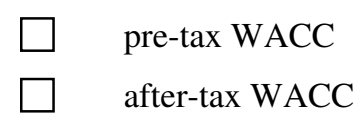

6. When taking into account sources of capital you usually proceed from:

\section{Current capital structure}

Target (or optimal) capital structure 
D. Questions about aspects related to corporate income taxation.

7. When calculating cash flows you usually proceed from:

pre-tax cash flows

after-tax cash flows

8. If you replied to question \#7 "after-tax cash flows": how do you transform cash flows onto after-tax level?

you proceed from the specific (dividend) payout ratio

you bring all the cash flows on after-tax level

9. When reckoning with corporate income tax you proceed from:

statutory corporate income tax rate

historical/current effective corporate income tax rate

forecasted (estimated) effective corporate income tax rate

All variants, depending on a valuation case

10. When forecasting corporate income tax liability by a company you take into account:

Only planned (supposed) dividend payments

Planned (supposed) dividend payments and other payments taxed

by corporate income tax (fringe benefits)

11. Do you account for any differences in valuing Estonian companies vis-à-vis non-Estonian ones proceeding from peculiarities of Estonian corporate income taxation?

In valuation of Estonian and non-Estonian companies we proceed from the same grounds

When valuing Estonian companies we make the following corrections:

When valuing Estonian companies using discounted cash flow (DCF) based models we make the following corrections:

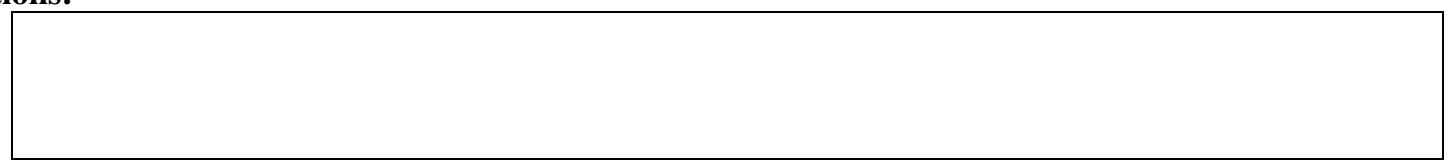

When using multiples to value Estonian companies we make the following corrections:

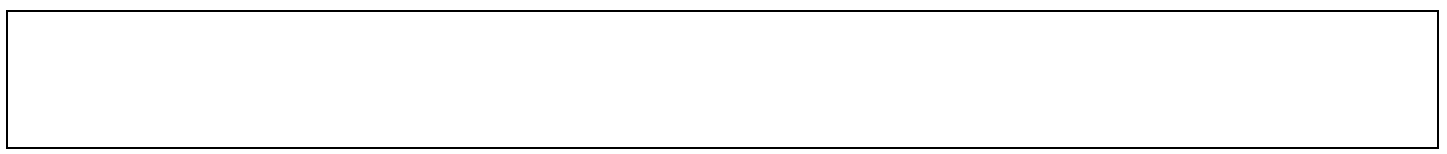

When using asset-based models to value Estonian companies we make the following corrections:

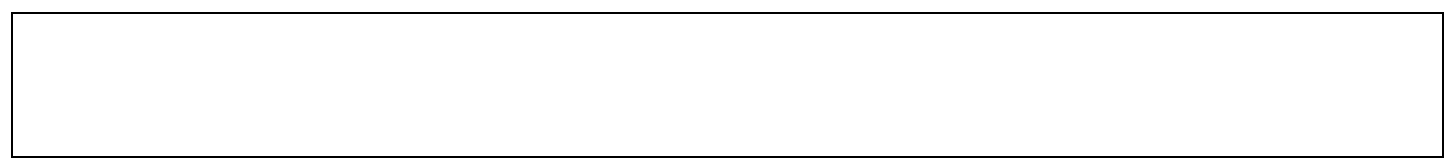

E. Please give your valuation opinion about equity value of the following hypothetical companies.

NB! When valuing please proceed $\mathrm{ONLY}$ from conditions related to a particular company!

\section{Company A}

Company's book value of assets is currently USD 2 million; it has no financial leverage, the company's return on assets (EBIT/Assets) is 20\%; cost of capital (WACC) is $15 \%$ and the dividend payout ratio is $50 \%$. Return on assets, cost of capital and the dividend payout ratio will remain constant; the company operates in a country where companies' profits are not taxed. The company operates eternally. (Please ignore and do not take into account any other, nonmentioned, piece of data!) 
Estimated equity value (USD):

\section{Company B}

The company B is a company registered and operating in Latvia. Its assets' book value is LVL 2.5 million, 30\% of them is financed by debt capital (debt ratio has been and will remain constant); interest rate on debt is $8 \%$ (fixed). The company B has the same return on assets, cost of capital and equity growth rate as the company A (these figures will remain constant). In Latvia corporate income tax rate is $15 \%$. The company operates eternally. (Please ignore and do not take into account any other, non-mentioned, piece of data!)

Estimated equity value (LVL):

\section{Company C}

The company $\mathrm{C}$ is a company registered and operating in Estonia. Its assets book value is EEK 15 million, 30\% of them is financed by debt capital (debt ratio has been and will remain constant); interest rate on debt is $8 \%$ (fixed). The company $\mathrm{C}$ has the same return on assets, cost of capital and equity growth rate as the company A (these figures will remain constant). Corporate income tax rate in Estonia is $21 \%$. The company operates eternally. (Please ignore and do not take into account any other, non-mentioned, piece of data!)

Estimated equity value (EEK): 